\title{
CHALLENGES IN IMPLEMENTING DECENTRALIZATION OF FOREIGN DIRECT INVESTMENT MANAGEMENT IN VIET NAM - CASE STUDY OF THE HUNG NGHIEP FORMOSA HA TINH STEEL PROJECT IN HA TINH PROVINCE
}

\author{
Au Thi Tam Minh*
}

\begin{abstract}
Over the past decades, an increasing number of developing countries in Asia have experimented with decentralization in varying degrees to achieve good governance and promote democracy. In Viet Nam, even though decentralization has been limited to de-concentration (or administrative decentralization), foreign direct investment (FDI) management is vigorously decentralized at the provincial level and has proven to be problematic. In one instance, it led to an environmental disaster in 2016. The objective of the present paper is to explore the factors resulting in ineffective decentralization of FDI management in Viet Nam, focusing on the challenges that the local government has been dealing with under the decentralization set-up, in particular with respect to environmental protection. Drawing on the case study of the Hung Nghiep Formosa Ha Tinh Steel project in Ha Tinh province, it is argued that Viet Nam continues to lack the essential prerequisites for effective decentralization. It is the time for Viet Nam to reconsider the policy of decentralization in the area of FDI management. Bearing in mind that economic development is vital, it should go hand in hand with environment protection in order to ensure the country's sustainable development.
\end{abstract}

JEL classification: H11, H77, P21, P33, Q58

Keywords: decentralization, foreign direct investment management, Hung Nghiep Formosa Ha Tinh Steel project, environmental protection, sustainable development

Researcher/lecturer of the Institute of State and Law - Ho Chi Minh National Academy of Politics, 135 Nguyen Phong Sac, Ha Noi, Viet Nam; Master of Public Policy - the Graduate School of Governance Studies, Meiji University, Tokyo, Japan (email: attm91@gmail.com). 


\section{INTRODUCTION}

Since the early 1990s, Viet Nam has taken steps towards administrative decentralization to make State management more efficient and to promote democracy at the local level. Foreign direct investment (FDI) management is one of the most strongly decentralized sectors. However, the decentralization of FDI management has not been implemented smoothly. Decentralization initially led to a "race to the bottom" among provinces to attract foreign investment (Vu, Le and Vo, 2007). Many low-quality projects were approved, including projects with high environmental risks. Notably, environmental disasters in four central coastal provinces in 2016, caused by the Hung Nghiep Formosa $\mathrm{Ha}$ Tinh Steel project, raised the alarm about the management of FDI in the context of decentralization from the perspective of environmental protection. This also resulted in an intense debate over the authority and responsibility of central and local governments in approving and overseeing the project as they blamed each other for the disaster.

Theoretically, decentralization is a sound idea, but it can be very challenging in practice and even result in negative impacts if it is not properly implemented. As seen under the decentralization set-up, an unprecedented environmental disaster occurred because of a FDI project in Viet Nam. The following question has been raised: What is wrong with the decentralization of FDI management in Viet Nam, or more directly: Why did this FDI project result in major environmental damage? By answering this question, the intention of this paper is to explore the reasons behind the ineffective decentralization of FDI management in Viet Nam, thereby providing some policy implications for effective decentralized FDI management for the sustainable development of the country.

The author uses the Hung Nghiep Formosa Ha Tinh Steel project in $\mathrm{Ha}$ Tinh province as an illustrative case study. This is because the case is notable in that it rang a warning bell on the management effectiveness of FDI under decentralization in Viet Nam, focusing on the approval and supervision of the project, in particular with respect to environmental management. The first part of the paper is comprised of an analysis of relevant documents to establish the background of the case study. A detailed description of the disaster resulting from the project is then presented along with debates on the effectiveness of decentralization in FDI management.

In addition, semi-structured interviews were conducted in $\mathrm{Ha}$ Tinh province in August 2018 to collect primary data for the case study. The interviews were designed to achieve in-depth information about difficulties or challenges in the decentralized management of FDI from local perspectives. Three interviews were conducted with four provincial officials, including an official from the Department of Natural Resources and Environment, officials from the Department of Planning and Investment, and an official from the Investment Promotion Center. The interviews took place at the head office of the Investment Promotion Center under the People's Committee of Ha Tinh province. 
Each interview lasted approximately one hour and was recorded by mobile phone. The interviews focused on the management of FDI in Ha Tinh province, including the role of FDI projects, difficulties faced by the local government in managing FDI under the decentralization strategy, and the controversy over the Hung Nghiep Formosa Ha Tinh Steel project incident, which took place in 2016. Based on an analysis of the case study, the challenges in the practice of decentralization in FDI management in Viet Nam is clarified in this paper.

\section{POLICY OF DECENTRALIZATION IN FOREIGN DIRECT MANAGEMENT IN VIET NAM}

In the development process, in addition to internal resources, countries rely on external resources, which consist of private capital flows (FDI), foreign portfolio investments and other financial flows, such as official development assistance (ODA) and international remittances. Among these external resources, FDI has remained a key source of finance and one of the least volatile flows to developing economies (UNCTAD, 2018, p. 12). As defined by the Organization for Economic Cooperation and Development (OECD), FDI is an investment by an individual or multinational enterprise of one country that establishes a lasting interest in and control over an enterprise in another country (cited in Greenlnvest, 2017, p. 7).

In developing countries, FDI has been considered an important source of private external finance, which accelerates growth and economic transformation. This type of investment not only contributes to the resources available and capital formation but it also results in the transfer of technology, skills, innovative capacity and organizational and managerial practices, and provides access to international marketing networks (OECD, 2002, p. 5). Because of its potential benefits to economic growth and poverty alleviation, developing and newly industrializing countries are very eager to attract FDI. Over the past decades, governments of developing countries have embarked on policy reforms that are more open to foreign investment with the objective to draw capital inflows. They have liberalized national policies to establish a favourable regulatory framework for FDI by relaxing rules pertaining to market entry and foreign ownership and have offered preferential treatment to foreign investors (Mallampally and Sauvant, 1999).

Similar to many other developing countries, attracting FDI is a key policy of Viet Nam in the post-renovation period. As a result of a serious crisis in the 1980s, the Communist Party of Viet Nam has put forward a comprehensive reform of the country, including a policy to attract foreign investment to develop the economy. The Law on Foreign Investment 1987 is the most important legal document formalizing the policy to receive FDI in Viet Nam. The country started to welcome FDI in 1988. Notably, from 
1988 to April 1989, the Ministry of Foreign Trade ${ }^{1}$ issued investment licences for FDI projects. In May 1989, the State Committee for Cooperation and Investment was established to deal with the function of State management of FDI. The licensing authority for foreign investment projects was therefore transferred to the State Committee for Cooperation and Investment.

The effort to decentralize FDI management in Viet Nam started in the 1990s, in line with the increased flow of FDI into the country during the post-renovation period. In particular, after the normalization of diplomatic relations with the United States of America and an embargo was removed in 1995, the number of foreign projects invested in Viet Nam increased rapidly, burdening the central Government with managing all the projects. During that time, the Government of Viet Nam acknowledged that decentralization was necessary to avoid overloading in the central agencies. Provinces that received large amounts of FDI tried to convince the central Government to decentralize the licensing of FDI projects. This was based on the view that decentralization could reduce the excessive concentration of power in a single management agency, which easily leads to a greater bureaucracy and authoritarianism and also reduces the dynamism and degree of autonomy of local authorities. In addition, decentralization would help to ease the complicated procedures associated with FDI projects, which, in turn, would result in favourable conditions to attract foreign investors. In summary, decentralization was raised as part of a State reform that could spur creativity in the local government and increase its participation in the process to deal with FDI and improve the efficiency of State management in all areas. In this context, decentralization of investment management became an important part in the trend to decentralize governance and was later was recognized as an important area for decentralization in the country.

Following the merger of the State Committee for Cooperation and Investment and the State Committee for Planning into the Ministry of Planning and Investment in 1995, the decentralization of FDI management was gradually implemented. From 1996 to 2005, the Government granted provincial governments the power to appraise and license FDI projects, limited by the capital size and area of investment. Except for strategically important areas, such as petroleum, insurance, banking and auditing, the People's Committee of $\mathrm{Ha}$ Noi and Ho Chi Minh City were authorized to license projects with registered capital of up to US\$10 million. Other provinces could license projects up to $\$ 5$ million. The management board of the provincial economic zones, industrial zones, export processing zones and hi-tech parks were allowed to license projects with a registered capital of up to $\$ 30$ million.

The Ministry of Foreign Trade was closed in 1990 following the restructuring of the government structure. 
In 2005, in line with the enactment of the new Investment Law, the management of FDI was almost completely decentralized to the provincial level. In the following year, the limit on investment size was removed, but the limit on investment area still applied. To be specific, except for a number of specialized projects, which are classified as conditional investment areas, provincial people's committees and management boards of economic zones have the authority to license all FDI projects, irrespective of the capital size. For projects deemed as being of national importance, approval from the prime minister in consultation with relevant ministries is required. In essence, decentralization in FDI management in Viet Nam has given the provincial governments almost full autonomy in granting FDI licences. The key agency dealing with FDI management at the provincial level is the People's Committee, which is assisted by the Department of Planning and Investment, and the management board of economic zones. The Department of Planning and Investment manages projects outside the economic zones and the management board of economic zones manages projects located within the economic zones. The interactions among agencies during the process to attain project approval are illustrated in figure 1.

\section{Figure 1. Interactions among agencies during procedures for approval of the project}

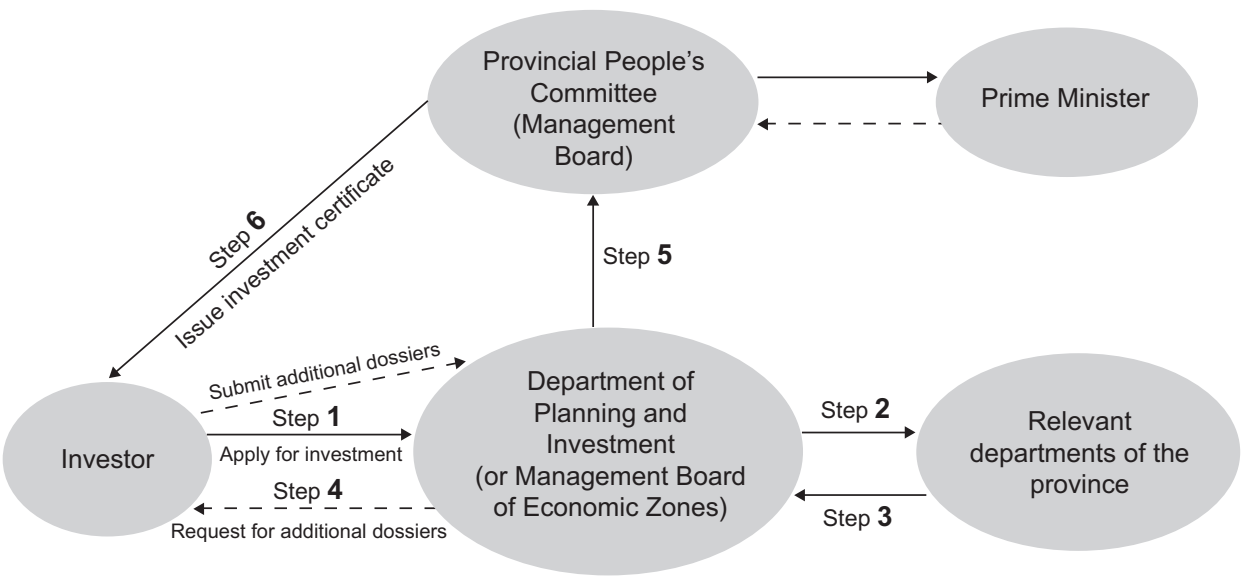

Source: X.H. (2016). 


\section{OVERVIEW OF THE HUNG NGHIEP FORMOSA HA TINH STEEL PROJECT IN THE VUNG ANG ECONOMIC ZONE IN HA TINH PROVINCE}

The establishment of the Vung Ang economic zone is an important milestone in the development process of Ha Tinh province. Located in the North Central coast, one of the least developed regions of Viet $\mathrm{Nam}$, Ha Tinh is an impoverished province whose economy is mainly based on agriculture. Among the 63 provinces of Viet Nam, Ha Tinh accounts for only 1.1 per cent of the national gross domestic product (GDP), as described in the Ha Tinh socioeconomic master plan to 2020 and vision to 2050 . $^{2}$ The plan to establish the Vung Ang economic zone is a major effort to boost the socioeconomic development of $\mathrm{Ha}$ Tinh in particular and the northern central region in general. The objective of the plan is to narrow the development gap with other regions of the country. Because of the impoverished conditions in Ha Tinh province, the prime minister approved a plan in 2006 for the construction of the Vung Ang economic zone and a deep sea water port linked to the economic zone in Ha Tinh province.

The Vung Ang economic zone is in the coastal district of Ky Anh in Ha Tinh. With a land area of 22,781 hectares, it covers nine communes of the Ky Anh district: Ky Nam, Ky Phuong, Ky Loi, Ky Long, Ky Lien, Ky Thinh, Ky Trinh, Ky Ha and Ky Ninh (figure 2). It is a multipurpose economic zone of various sectors, including industries, trade, services, tourism, urban centres, agriculture, forestry and fisheries, in which the development of the metallurgy industry, industries related to seaports, labour-intensive industries and export-processing industries are promoted. ${ }^{3}$ The multipurpose economic zone was set up with the intention to attract foreign investors. Notably, the port provides a link to the Lao People's Democratic Republic and Thailand. The Management Board of the economic zone was established with the mandate to supervise planning and construction activities and report to the Ha Tinh government (Wit and others, 2012, p. 6). The Provincial People's Committee has the authority to appoint staff of the Management Board, which, in turn, has the authority to license the projects invested in the economic zone. As of 2012, the Vung Ang economic zone had more than 90 licensed projects with a total registered capital of 240 trillion Viet Nam dong ( $\$ 10$ billion) (Wit and others, 2012, pp. 16-17).

Decision No. 1786/QD-TTg of 27 November 2012.

Decision No. 72/206/QD-TTg of 3 April 2006. 
Figure 2. Location of Ky Anh district in Ha Tinh province, Viet Nam

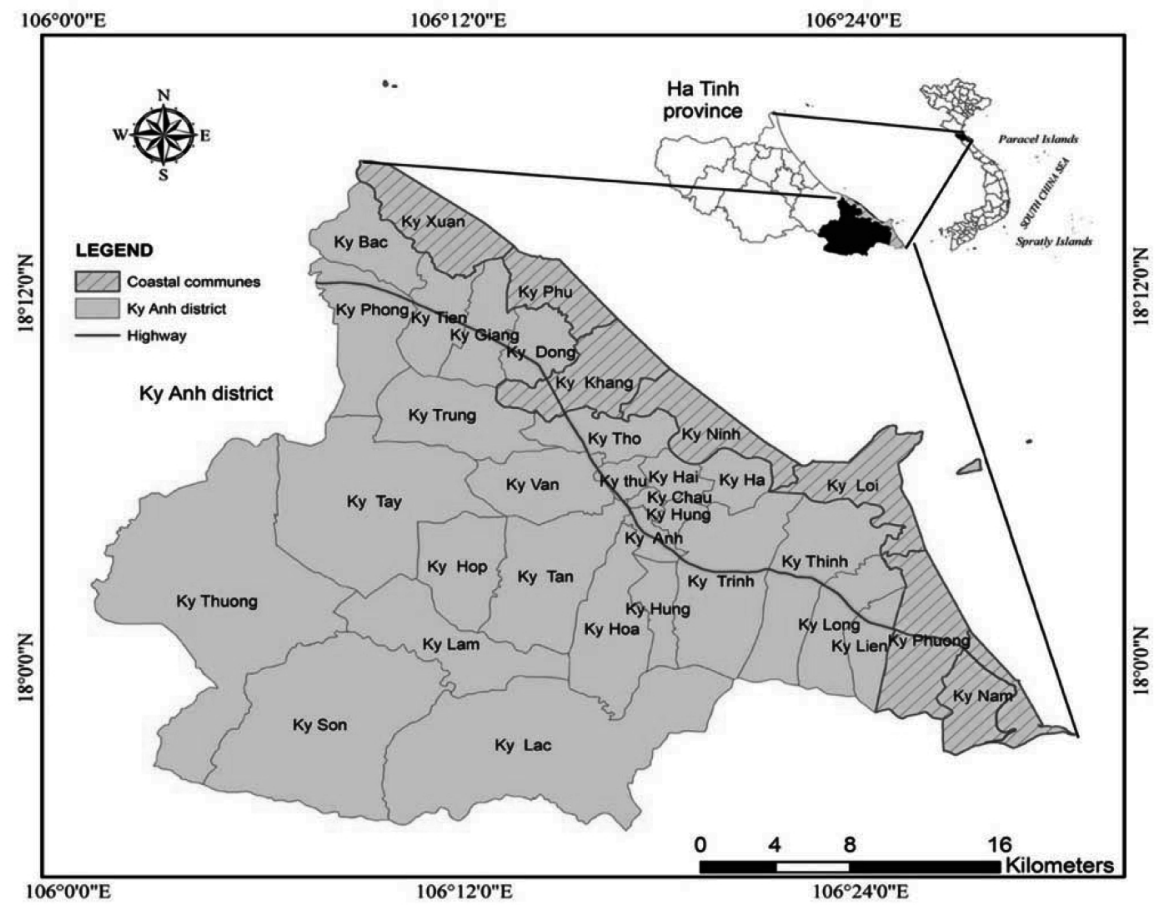

Source: Nguyen and Hens (2019).

Note: The boundaries and names shown and the designations used on this map do not imply official endorsement or acceptance by the United Nations.

\section{Hung Nghiep Formosa Ha Tinh Steel project in the Vung Ang economic zone}

The case study in this paper involves a project established in the Vung Ang economic zone set by the Hung Nghiep Formosa Ha Tinh Steel Company under the backing of the Formosa Plastics Group, which is based in Taiwan Province of China. The project for an integrated steel mill and Son Duong port was granted an investment certificate in June 2008. It covers an area that exceeds 3,300 hectares and has the total chartered capital of approximately $\$ 10$ billion (phase I); under phase II, the capital is expected to increase to $\$ 27$ billion (Phuong Linh, 2014). This is currently the largest FDI project in Viet Nam. The land lease period for the project is 70 years and the land rent is more than 96 billion Viet Nam dong for the whole lease period (Minh Hong, 2014). Construction of the steel plant began in 2012 after three years of waiting for site clearance. The plant entered the production stage in May 2017 with the operation of the first blast furnace; the operation of the second furnace was launched in May 2018. 


\section{THE HUNG NGHIEP FORMOSA HA TINH STEEL PROJECT ENVIRONMENTAL DISASTER IN 2016 AND THE DEBATES ON DECENTRALIZATION OF FOREIGN DIRECT MANAGEMENT IN VIET NAM}

In April 2016 an unprecedented marine environmental disaster occurred on the central coast of Viet Nam, attracting attention across the country. Massive deaths of fish spread from Ha Tinh province to the other three provinces along the North Central coast of Viet Nam. On 6 April 2016, off the coast of Ky Anh district in Ha Tinh province, local people discovered large amounts of dead fish floating in the sea. Starting on 10 April 2016, dead fish were found along the coast of Quang Binh province. From 16 April to 19 April 2016, dead fish were also found along the coastline of Quang Tri province. In Thua Thien Hue province, dead fish were found washed up on the beaches from 15 to 21 April 2016. Tons of fish carcasses floated on the sea and washed ashore every day until 4 May 42016 (figure 3). For the first time the people of Viet Nam witnessed large-scale deaths of fish, which caused panic.

Figure 3. The spread of dead fish along the North Central coast of Viet Nam, April 2016

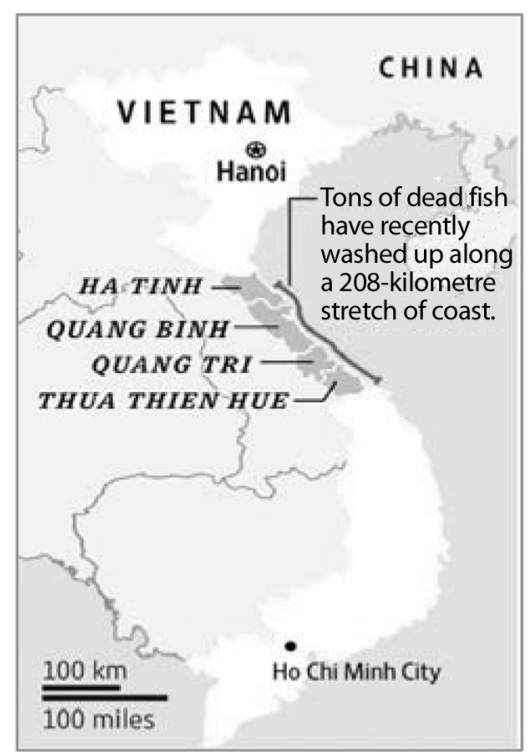

Source: Hookway (2016).

Note: The boundaries and names shown and the designations used on this map do not imply official endorsement or acceptance by the United Nations. 
A long investigation of the incident was conducted, stirring up a lot controversy and turmoil among the general public. During that time the Hung Nghiep Formosa Ha Tinh Steel Company was suspected to be the culprit behind the massive deaths of fish, as large sewage pipes that connected the plant with the ocean had a strong odor at the mouth of the pipes where wastewater was discharged into the sea. The company denied any responsibility for the disaster and insisted that the discharged wastewater was properly treated. In the initial stage of the investigation, the Government also indicated that the cause of the disaster might be natural (red tide or algal bloom phenomenon), as there had been no evidence proving the company was involved in the mass fish deaths. On 25 April 2016, a spokesman for the company issued a shocking statement. The company spokesman suggested that Viet Nam choose either fish or steel. In other words, he suggested that the Vietnamese should decide if they want to catch fish or to build a modern steel industry. This statement provoked a fierce public outcry. In late April 2016, the first protest in Quang Binh province marked the beginning of multiple marches and protests in which thousands of Vietnamese called for a clean environment, government transparency and the disengagement of the Hung Nghiep Formosa Ha Tinh Steel Company. Larger demonstrations took place in Ha Noi and Ho Chi Minh City in early May 2016.

After two months of the investigation, it was concluded in late June 2016 that the plant of the Hung Nghiep Formosa Ha Tinh Steel Company caused serious pollution of the sea, leading to massive death of fish along the central coast of Viet Nam. The Government report indicated that the cause of the massive death of fish could be attributed to the plant's wastewater. It contained toxic chemicals, such as phenols, cyanide and iron hydroxide, that exceeded the permitted level and was released into the sea during the plant's test run phase. In addition, 53 violations in the process of construction and the test run of the production lines were discovered, including an unauthorized change to a dirtier production technology, ${ }^{4}$ which released a lot of toxic waste, and the lack of wastewater treatment, as committed in the approved environmental impact assessment report. Admitting its responsibility for the wrongful discharge of toxic chemicals in the sea, the company apologized to the Government and the entire population of Viet Nam and agreed to pay $\$ 500$ million in compensation for the incident, which is considered to be one of the worst environmental disasters in the modern history of Viet Nam.

Local economies were heavily affected by the disaster as many depend on seabased industries, such as fishing, aquaculture and sea tourism, which stagnated following the disaster. The total value of damage declared was approximately 1,947

Regarding the unauthorized change of production technology, the company deliberately changed from dry coke quenching technology committed in the environmental impact assessment to wet coke quenching technology, which is more polluting. The dry coke system is modern and cleaner, but more costly. 
billion Viet Nam dong (Ha and Dang, 2017). The disaster also had a very negative impact on society in general. In addition to concerns about food safety, the incident also brought about social insecurity, as local people worried about loss of livelihood, unemployment, debt and bankruptcy. The Government acknowledged that the incident reduced people's confidence in the Government. People questioned the process used to appraise and approve the investment, and the ability of the authorities to respond to the emergency, as indicated in the following comment made by an environmental consultant: "Vietnamese who are rarely consulted about and aware of investment projects face a big crisis of confidence" (Nguyen, as cited in Pham and Chau, 2016). Regarding the environment, it is considered to be "the most serious environmental disaster Viet Nam has ever faced" (Mai and Yu-Huay, 2016); the environmental damage caused by the disaster cannot be denied. The discharge of toxic chemicals from the plant polluted 200 kilometres of coastline. The marine ecosystem was severely affected, with more than 100 tons of fish killed and coral reefs destroyed (Huu Tuan, 2016). It will probably take decades for the regional marine environment to completely recover from the toxic spill.

After the incident, several measures were taken to deal with the discharge from the steel plant. The Ministry of Natural Resources and Environment set up an interdisciplinary council to monitor the remedial measures. The company was required to set up biological indicator ponds to monitor the quality of wastewater. In addition, the company cooperated with Ha Tinh province to invest in an industrial waste treatment plant. To date, Hung Nghiep Formosa Ha Tinh Steel Company has rectified 52 out of the 53 violations. The only issue still remaining is technology conversion. The company has committed to a change in the production technology by 2019. With support from the Ministry of Natural Resources and Environment, the Ha Tinh Department of Natural Resources and Environment is operating an online monitoring centre that is connected directly to the unloading point of the plant to supervise the discharge from the plant. The sea appears to be recovering. Fishermen have started fishing again though the amount of fish caught is very limited.

Debates on the effectiveness of decentralization in the field of foreign direct investment management using the case of the Hung Nghiep Formosa Ha Tinh Steel project as an example

The following includes highlights from debates on the effectiveness of the decentralization of FDI management.

Decentralization of FDI management has brought about positive impacts on local administration and the development of Ha Tinh province.

It cannot be denied that the decentralization policy helps to increase local autonomy and the activeness of the local government. According to an official of the 
Department of Planning and Investment of Ha Tinh province (personal communication, 24 August 2018), "decentralization policy makes the local government more proactive. Based on local development plans and its own strengths, the local authority sets out specific policies to attract investment in areas where the province has comparative advantages". In addition, decentralization encourages the simplification of administrative procedures in FDI management, as the implementation of investment procedures at the local level is more rapid and simpler. Moreover, in order to create a favourable investment environment, the provincial government has also made efforts related to public administration reform, while supporting businesses to complete the necessary procedures, as stated by a Ha Tinh Investment Promotion Center official.

Ha Tinh province has attracted projects, which substantially contribute to the local development in many aspects. From an economic perspective, the inflows of FDI have helped to increase local revenue and facilitated the restructuring of the local economy by raising the proportion of the industrial sector in the economic structure (personal communication, 24 August 2018). In fact, one official of the Department of Development and Planning pointed out that owing to large FDI projects, the economic growth rate of Ha Tinh increased to more than 30 per cent in 2017, compared to only 9 to 10 per cent in the previous years (personal communication, 24 August 2018). From a socioeconomic perspective, FDI projects have helped to create jobs and improve the lives of local people, while from a political perspective, $\mathrm{Ha}$ Tinh has become one of the popular investment destinations of the country (personal communication, 24 August, 2018). In particular, the Hung Nghiep Formosa Ha Tinh Steel project is a very crucial FDI project. In addition to contributing significantly to the local budget, it has facilitated "vibrant development for the region and promotes the development of other economic sectors" (personal communication, 24 August 2018).

\section{Negative impacts of decentralization on FDI management at the local level}

Despite the beneficial effects of decentralization of FDI management, there are concerns that it has resulted in lax management of FDI projects, which, in turn, led to the environmental disaster in 2016. Arguably, the local authority has sought to attract FDI projects without careful consideration. When looking back on the licensing process for the Hung Nghiep Formosa Ha Tinh Steel project, it is surprising that such a large project with wide-ranging impacts and high environmental risk was approved so easily despite sketchy reports. Even though the former chairman of the People's Committee indicated that the appraisal and approval of the project were carried out under the "right procedure" and "agreed to by 12 ministries" (Vnexpress, 2016), the approval of the project was undoubtedly a risky decision. This project belongs to the category of industries with high environmental risks. Furthermore, its parent company was notorious for being involved in many environmental damage cases in Cambodia and the United 
States. In Taiwan Province of China, the company was on the list of the top-10 polluters as pointed out by the Ethecon Foundation. ${ }^{5}$

Moreover, the Hung Nghiep Formosa Ha Tinh Steel project received extra-legal incentives from local authorities. Regarding land lease, the Investment Law 2005 stipulates that the provincial government can only grant land leases up to 50 years, except in the case of necessity where the Government shall decide a longer term for the project. Nonetheless, an investment licence was granted for 70 years. This violation was pointed out by the Government Inspectorate in 2015. However, it was not rectified as the prime minister agreed to keep the 70-year lease term in order to ensure the stabilization of the project. Notably, it should be emphasized that the extension of this land lease term did not receive approval from the prime minister from the beginning (Hoang, 2016). As Ha Tinh was a poor province and eager for investment capital at that time, the approval of a highly risky project along with extra-legal incentives might imply that the local authority accepted risky projects for the sake of economic development without rigorous consideration, especially in terms of the environment. It also suggests that when power is vested in the local government, it can be used ineffectively, wrongly or abused in a way that may harm the society, such as in the case of the Hung Nghiep Formosa Ha Tinh Steel project disaster in 2016.

The disaster also exposed the weaknesses in the supervision of the project after the approval. Because of the lax monitoring process, serious violations were not promptly discovered, eventually leading to a terrible marine life disaster. It was not until the incident that, 53 violations committed by the company, including the unauthorized change to dirtier technology, were discovered. The Ministry of Natural Resources and Environment official explained that the Ministry conducted an inspection in May 2015, but at that time the plan was still under construction. Hence, the inspection was limited only to some items and the technology issues were not reviewed (Thu Trang, 2016). Nevertheless, the monitoring of the project should have been conducted on a regular basis with coordination of the authorities at all levels. No violations were found until the disaster occurred, indicating that relevant State agencies had not fulfilled their responsibilities.

\section{Regarding the intergovernmental relations and the issue of accountability}

A notable issue that has emerged after the disaster was the confusion in determining the scope of responsibility among State agencies involved in the project, which was closely associated with decentralized FDI management. Concerning project approval procedures, although the Management Board of the Vung Ang economic zone was the body that granted the investment certificate to the Hung Nghiep Formosa $\mathrm{Ha}$

See www.ethecon.org/en/902. 
Tinh Steel Corporation, project approval was needed from the central Government based on consultation with relevant ministries. Eight years since the licensing of the project, almost all the relevant ministries, such as the Ministry of Science and Technology, the Ministry of Industry and Trade and the Ministry of Natural Resources and Environment, have denied any responsibility by emphasizing the decisive role of the local government in managing the project.

Remarkably, there was confusion over responsibilities in monitoring the project between the central and local governments, specifically from the perspective of environmental protection. The Ha Tinh government has insisted that the main responsibility for environmental supervision rested with Ministry of Natural Resources and Environment, as the authority to approve the environmental impact assessment belongs to this Ministry. The Ministry of Natural Resources and Environment has argued that although approval of the assessment was the responsibility of the Ministry, monitoring the implementation of the project was to be handled by relevant authorities, including the People's Committee of Ha Tinh. Accordingly, the provincial authorities were tasked with the direct supervision of the project (Nam Phuong, 2016). The unclear determination of responsibilities related to the project ultimately led to the shirking of responsibilities among State agencies.

\section{CHALLENGES IN THE IMPLEMENTATION OF DECENTRALIZATION IN FOREIGN DIRECT INVESTMENT MANAGEMENT THROUGH THE CASE STUDY OF HUNG NGHIEP FORMOSA HA TINH STEEL PROJECT}

Evidence shows that decentralization led to negligence with regard to FDI management, especially at the local level. Consequently, tasks were not carried out in a strict and effective manner, resulting in serious consequences such as the Hung Nghiep Formosa Ha Tinh Steel project disaster. In addition, State agencies tended to shift the responsibility to each other when the problem occurred. In exploring the reasons behind these issues, six main themes were identified through in-depth interviews with $\mathrm{Ha}$ Tinh officials. Below is a discussion of predominant challenges acknowledged by the local government officials in managing FDI projects under the decentralized set-up in Viet Nam, which have emerged from the case study.

\section{Limited competence of the local government}

One of the key challenges for the local government to carry out the responsibilities associated with decentralized FDI management is its limited appraisal competence, specifically in collecting and evaluating information about potential investors and investment projects during appraisal procedures. Personal interviews with officials of $\mathrm{Ha}$ Tinh Department of Planning and Investment have revealed that the project appraisal 
was mainly based on the reports submitted to local agencies by investors. Information about investors is basically investigated through the Internet, which is often incomplete and difficult to verify. In particular, the authorities face great difficulties when dealing with new investors: "If an investor has already invested in Viet Nam, we have channels to collect information. However, if it is a first-time investor in Viet Nam, collecting information is very difficult, sometimes information is also unavailable on the Internet". Moreover, "new technology makes appraisal difficult because of inadequate local competency" (personal communication, 24 August 2018).

Limited technical and managerial competence also poses challenges for local authorities in the supervision of FDI projects. Local governments appear to lack adequate competence to effectively monitor these projects, as the projects are often large and apply complex technology, while the knowledge and ability of local authorities are limited. In particular, local authorities lack the capability to evaluate and manage some of the more advanced technologies, according to a Ha Tinh Department of Natural Resources and Environment official (personal communication, 24 August 2018). In response to questions from press agencies about the failure in monitoring of Hung Nghiep Formosa Ha Tinh Steel project, the Ha Tinh government has admitted that it "never has dealt with such a big project and that the required technical equipment for inspection and supervision was also lacking. In fact, the Ha Tinh Department of Natural Resources and Environment conducted the inspection but failed to detect any violations because of the lack of technology" (Vnexpress, 2016).

\section{Insufficient resources at the local level}

The weak level of competence at the local level in performing decentralized functions is closely associated with insufficient resources, including human resources, financial resources and technical resources. First, environmental supervision is inefficient because of a staffing shortage, as exemplified by the Department of Natural Resources and Environment official: "human resources is limited by a personnel quota as well as the salary fund, while the natural resources and environment sector requires a direct work force". The official notes that in comparison with southern provinces, staff devoted to the environment issue in the Ha Tinh province were four to five times fewer. Although the southern provinces have more projects, insufficient manpower responsible for environmental monitoring is still significant for Ha Tinh: "They (governments of the southern provinces) have dozens of environmental inspectors, while here (Ha Tinh province) there are only one or two people". He also has criticized the policy of staffing reductions, as it applies to the entire State machinery without taking into account the characteristics of each sector:

There are sectors and agencies with heavier workloads; they need more personnel. In particular, environment management is a sector that requires employees to go to the field, and the environment has a long-term impact on 
the development of society. It can affect the economy and other industries, but now environment management is also part of the general trend of staff reduction (personal communication, 24 August 2018).

In addition, funding for the environment sector is very limited, especially in poor provinces, such as Ha Tinh. The Department of Natural Resources and Environment official admits with hesitation that the budget for the environment is small: "In the southern provinces, investment in the environment meets the requirements, while in $\mathrm{Ha}$ Tinh province, it is very limited" (personal communication, 24 August 2018). As a result of budget constraints, there is a lack of specialized analytical equipment for environmental monitoring. Local agencies do not have waste analysis equipment. Some chemical compounds used in wastewater, such as phenol and cyanide, cannot be analyzed at local agencies, and need to be sent to large laboratories to be analysed (personal communication, 27 August 2018). It is evident that the local government cannot fulfill its responsibilities to supervise the FDI projects with its limited resources. Implementing decentralization without accompanying it with the required resources results in management inadequacies. The Department of Natural Resources and Environment official has also raised this issue and asked for support from the central Government:

The current decentralization regulations have limitations when considering issues, such as human resources and equipment, especially equipment which is difficult for local governments to invest in on their own. If decentralization of authority were to come with support from the central Government for investment in equipment, it would be more effective (personal communication, 24 August 2018).

\section{Inadequacies in specialized legal framework}

Another important factor behind the lax supervision of the FDI project is related to the permissive licensing procedures. To attract investors, the law on investment has been relaxed to a large extent, thereby easing market entry for foreign investors. As described by the Department of Planning and Investment official, the entry regulations are not strict enough and the investment procedures do not provide enough details for collecting detailed information. He notes the following:

Unlike a public investment project that requires a feasibility report and then the authorities verify all the items in the report; for this (FDI project) no one appraises it. The authorities only check documents submitted by investors and consider the appropriateness with local development planning and local land use planning. In terms of the environment, after being licensed, investors make an environmental impact assessment (personal communication, 24 August 2018). 
In addition, the relevant legal provisions are contradictory. As pointed out by the local officials, the Law on Investment and the Law on Environmental Protection contradict each other. The Law on Environmental Protection requires an environmental impact assessment prior to investment approval as a basis for project approval, while the Investment Law does not stipulate this. This causes confusion for local agencies when performing their functions. The officials also have indicated that "if an investor is required to make an environmental impact analysis and it is is not approved for investment, the question is who will bear this cost", implying that in reality the environmental impact analysis, which is an essential tool to evaluate environmental impacts of projects, is often omitted. With such legal loopholes, the existence of risky projects, such as the Hung Nghiep Formosa Ha Tinh Steel project is inevitable.

Not only are the provisions related to the approval of FDI projects not strict enough, but the regulations on project supervision are also incomplete, especially with regard to environmental regulations. In reviewing the Hung Nghiep Formosa Ha Tinh Steel project case study, it was noted that press agencies had criticized the Ha Tinh authority for licensing this project even though the investor had a bad reputation for polluting the environment in some other countries. An official of the Ha Tinh Department of Planning and Investment attributed this issue to the weak State management system or poor management capacity, emphasizing the lack of regulations on environmental criteria to supervise the projects efficiently. "Sometimes the authorities know about bad information, but because of their subjective will, they think that investors, when investing in Viet Nam, must follow our standards which we can supervise so that no mistake occurs. However, in the end, due to poor management capacity, mistakes have occurred. We do not even have regulations on fixed criteria, for example, there are no regulations on environmental monitoring systems", he said. In his view, this relates to "management inadequacy from the ministry level" and a "systematic issue" (personal communication, 24 August 2018). The Department of Natural Resources and Environment official also affirmed that there were no mandatory regulations for the projects to have an online monitoring system. The installation of an online monitoring system to oversee the discharge from the project, with the aim to avoid similar disasters, was required only after the Hung Nghiep Formosa Ha Tinh Steel project disaster had occurred: "If this disaster had not happened, perhaps there would have been no online monitoring system even now", he said (personal communication, 24 August 2018). The investigation of the disaster has revealed loopholes in the law on investment and environment, including the lack of standards for the construction of waste treatment facilities and monitoring system.

Furthermore, the management of FDI projects faces impotent regulations concerning sanctions to deal with violations. In the case of the Hung Nghiep Formosa Ha Tinh Steel project disaster, it is contended that the punishment for violations caused by the company, including a compensation of $\$ 500$ million, is not based on any legal standard. There is an opinion claiming that this violation should have been treated as 
a criminal offense, instead of as only an administrative offense. Questions were posed about the compensation of $\$ 500$ paid by the company: "What if the money is not enough to compensate the people? Do localities have to overcome the shortfall themselves?" (Nhi, 2016) There is a popular belief that if enterprises violate the regulations, State agencies may withdraw the investment license of the project. Nonetheless, the application of sanctions to FDI projects is very difficult. As indicated by local officials, project withdrawal is difficult as it leads to lawsuits:

Because after allocating land to the project, the investor has assets on the land, that is why taking back the land is difficult. Many lawsuits have lasted more than ten years. When the lawsuit takes place, especially international lawsuits, the situation becomes very complicated. Our law now is relaxed, but handling post-licensing situations is not easy. Regarding current sanctions, in addition to administrative sanctions, the cases where project withdrawal can be applied are limited to only a few conditions. There are many conditions for withdrawal that cannot be applied (personal communication from a local official, 24 August 2018).

\section{Weak coordination mechanism associated with unclear distribution of responsibilities between State agencies}

Another challenge that local governments are facing regarding decentralized FDI management is the lack of coordination between central and local agencies. When asked about shifting the responsibility among agencies related to Hung Nghiep Formosa Ha Tinh Steel project disaster, the Department of Planning and Investment official has explained that the unclear mechanism of coordination led to the confusion in determining the accountability among relevant agencies. He has added the following: "Probably not only Ha Tinh but also for other localities, there is a lack of coordination between the local and the national ministries", implying that coordination is weak throughout the whole system (personal communication, 24 August 2018).

In fact, the roles and specific tasks of each party under the coordination mechanism has not been clarified, in particular the defining of the coordinating role. The most prominent accountability dispute in the Hung Nghiep Formosa Ha Tinh Steel project case is related to the function of environmental supervision between the Ministry of Natural Resources and Environment and local authorities. The official from Ha Tinh Department of Natural Resources and Environment has asserted that the role of the provincial authorities concerning environmental supervision is defined as a coordinating role, meaning that provincial agencies are only to participate when asked by the agency that assumed the main responsibility, i.e. Ministry of Natural Resources and Environment. Accordingly, local authorities are tasked with the coordinating function without assigning specific tasks: "The mechanism is not clear. Because we hold the coordinating function, we can only take coordinated actions as requested; we cannot 
take the initiatives relating to monitoring and conducting inspections. Local authorities cannot arbitrarily conduct inspections when there is no regulation" (personal communication, 24 August 2018). In essence, the lack of coordination among State agencies stems from unclear distribution of responsibilities among relevant agencies.

Evidently, weak coordination and unclear distribution of responsibilities between central and local agencies has undermined the significance of decentralization as a strategy to increase local responsiveness and accountability. Because of better access and frequent interactions at the local level, it is clear that local authorities have an advantage over central agencies to carry out daily monitoring of the projects. However, the absence of specific regulations in this regard, and the unclear assignment of tasks among relevant agencies make it difficult for local authorities to conduct monitoring activities regularly. Because of this, the offices of the provinces are often passive and depend on the central agencies' plans and directives (personal communication, 27 August 2018). Furthermore, the confusion associated with the coordinating role weakens the sense of responsibility among local agencies, as they do not recognize the legal binding of any particular responsibility. Consequently, public accountability has deteriorated, resulting in the Hung Nghiep Formosa Ha Tinh Steel project disaster, which, in turn, has incited public outrage and led to the uncovering of a series of serious violations, an inevitable consequence of inadequate monitoring and irresponsibility of the authorities. Empowerment of the local government without accompanying it with accountability may create gaps in management, and make decentralization counterproductive.

\section{The dilemma concerning economic development and environment protection}

It has been revealed that State agencies, especially local government, has encountered the dilemma of economic development or environment protection while pursuing FDI projects. To foster development, Viet Nam has promoted foreign investment in many key industries that have high environmental risks, such as heavy industries. It would be ideal if attracting investment and protecting the environment could be achieved concurrently. This, however, is a pressing issue for local governments and the central Government. Though the Government has stated its preference for projects that are environmentally friendly and high-tech in nature, many projects of low quality and with high environmental risks are ongoing in many provinces.

It is worth noting that many developing countries, including Viet Nam, have attracted foreign investment, partly owing to low environmental cost. The reason a discharge monitoring system was not required even for such a large huge and risky project, such as the Hung Nghiep Formosa Ha Tinh Steel project, is related to investment costs and the investment promotion issue, as stated by an official of the $\mathrm{Ha}$ Tinh Department of Natural Resources and Environment: "Operating this (discharge monitoring system) is very expensive, costing tens of millions of dollars annually, and 
only large businesses can afford it. If it is mandatory for them to install the system, the environmental costs will be very high. Then, of course the ability to attract investment will decrease" (personal communication, 24 August 2018). He has also argued that economic development is the priority at the country's current level of development: "At this stage we have to accept that because we need economic development. When the economy is more developed, we may raise the environmental costs, remove the 'dirty' guys, open to the 'clean' ones. This is for the later stage and it requires consideration at the national level with environmental criteria" (personal communication, 24 August 2018). Presently, the pressure for economic development in Viet Nam is coercing local governments, especially those representing poor provinces, to more readily accept risky projects for the sake of economic growth while ignoring potential environmental impacts. In addition, as indicated by the Department of Natural Resources and Environment official, the number of inspections has been reduced to avoid disrupting the operation of businesses. This preferential policy is limiting environmental supervision of foreign invested projects.

\section{Lack of public participation}

In retrospect, with regard to the Hung Nghiep Formosa Ha Tinh Steel project case, the absence of public participation in the decision-making process and the post-approval supervision need to be reviewed. When the investor applied for an investment licence, during the appraisal period, the provincial government was required to consult with the relevant local departments. After that, the interactions between the local government and the central government and among relevant State agencies to facilitate the approval of the project took place. According to the regulations, within 13 days after granting approval of the investment, the project information must be sent to the relevant departments so that they can deal with matters within their jurisdictions. It appears that the decision-making process for an investment project inside the economic zone failed to involve public participation. The process of appraisal and approval was closed to State agencies. During the operation of the project after approval, the role of public supervision became more limited, as there was no specific mechanism to involve people participation. Viet Nam has issued many regulations to require public participation, ensuring the role of sociopolitical organizations and communities, especially at the grass-roots level, in monitoring and contributing opinions for policies, plans, programmes and socioeconomic projects. Despite this, a mechanism for the general public to monitor foreign investment projects does not exist. The Hung Nghiep Formosa Ha Tinh Steel project disaster has raised the issue of promoting the role of sociopolitical organizations and local people in evaluating and monitoring projects. This fits well with the Vietnamese motto "People know, people discuss, people do, people check" on public matters, including FDI management. 


\section{CONCLUSION}

In general, decentralization is neither completely positive nor negative. If designed well, it can move decision-making closer to the people and improve the efficiency of State management. If not, it will have adverse effects. The process of decentralization is extremely complicated, as it involves many factors, which individually and interactively affect outcomes, particularly for developing countries.

In Viet Nam, under the decentralization strategy, the authority of investment management has been strongly decentralized to the local government. Despite the potential positive impacts, decentralization has resulted in lax supervision of FDI projects, which has directly affected the sustainable development of the country. The approval of risky projects, such as the Hung Nghiep Formosa Ha Tinh Steel project, has resulted in serious consequences, specifically with respect to the environment.

What is striking about the situation of decentralization of FDI management in Viet $\mathrm{Nam}$ is that the local government has been given large authority to promote, attract, facilitate and approve investment projects especially in poor areas, such as Ha Tinh province, even though it lacks the capacity to do so. In other words, local governments do not have sufficient competence and resources to carry out these delegated functions. Furthermore, as a result of the pressure to foster economic development, the local government has tended to favour large-scale projects without paying due attention to the potential environmental impacts. In addition, because of the lack of coordination and the confusion about the extent of authority between the local and central government, no authority has assumed responsibility for monitoring the projects. Combined with other issues, such as an inadequate specialized legal framework and lack of public participation, these are important reasons why decentralization of FDI management in Viet Nam has not worked properly. Significantly, the Hung Nghiep Formosa Ha Tinh Steel project's environment disaster happened as a result of the accumulation of these issues.

The investor is arguably responsible for the environmental damage, but the responsibility of all State agencies from the central to local levels in investment management and minimizing risks is obvious. Without clarifying the responsibilities of the involved parties along with a strict accountability mechanism, such environmental incidents are inevitable.

The case of the Hung Nghiep Formosa Ha Tinh Steel project has clearly demonstrated that in the context of decentralization, Ha Tinh authorities have faced great challenges in managing FDI projects. Decentralization has been vigorously implemented while local capacity has failed to attain the required skills to be effective. Intergovernmental relations have remained an obstacle to decentralization; the civil society is not strong enough; and the pressure of economic development, coupled with 
inadequate regulatory framework, induces unpredictable consequences, which can be harmful to the environmental and social welfare. The evidence from this study supports the view that several prerequisites need to be in place in order to ensure beneficial outcomes of decentralization.

In particular, these findings suggest that decentralization of FDI management needs to be reconsidered in several ways. Arguments can be made against implementing a decentralization strategy because of the incompetence of local governments in performing delegated functions. Though it is true that local government authorities do not have the capability to make complex decisions regarding investment projects, the same can be said about the central Government authorities. It is uncertain if such a disaster could have been avoided if the project had been fully under the authority of the central Government, while the benefits of decentralization are undeniable if it is smoothly implemented. The issue is not that local governments should not have the authority to undertake investment decisions. The issue is perhaps that there should be clarity regarding the scope and areas of authority between local and central authorities, and a proper coordination process between the two levels of government. It is worth noting that decentralization per se is not the problem, but instead the problem is related to the way it has been implemented. Without being designed or implemented properly, decentralization may have negative impacts. Adverse effects on environmental is one possible consequence of the decentralization in FDI management. In these cases, decentralization is deemed to be "good in theory, but bad in practice" (Lalitha, 2002, p. 138).

By reviewing the Hung Nghiep Formosa Ha Tinh Steel project case in depth, the challenges and risks in FDI management under decentralization, especially in poor regions, which are desperately in need of investment but have limited managerial capacity, are illuminated. This study has important implications for more effective management of similar FDI projects in underdeveloped regions in future. In this paper, the central argument maintains that adequate delivery mechanisms for decentralization needs to be in place in a systematic way in order to achieve effective decentralized management. This entails an adequate regulatory framework on the management of FDI, a clear demarcation of responsibilities and accompanied accountability among State agencies, a proper coordination process between local and central government, increased local capacity and active participation of the civil society. Further research with more refined data could make it possible to explore this topic more fruitfully. 


\section{REFERENCES}

Ha, V., and S. Dang (2017). Environmental incident in the central coast, one year look back, 4 April. Available at http://infonet.vn/su-co-moi-truong-bien-mien-trung-1-nam-nhin-lai-post224600.info (In Vietnamese).

Hoang, A. (2016). Does Vo Kim Cu "ignore" the conclusion of the Government Inspectorate on Formosa?, 26 July. Available at https://nongnghiep.vn/ong-vo-kim-cu-co-phot-lo-ket-luan-cuathanh-tra-chinh-phu-ve-formosa-post170555.html (In Vietnamese).

Hookway, J. (2016). Vietnam's dead fish breathe life into protest movement. Wall Street Journal, 19 May. Available at www.wsj.com/articles/vietnams-dead-fish-breathe-life-into-protest-movement1463692409.

Huu Tuan (2016). Government report on Formosa case: monitoring FDI from the perspective of environmental protection is very urgent, 28 July. Available at http://baodautu.vn/bao-cao-cuachinh-phu-ve-vu-formosa-giam-sat-fdi-tu-goc-do-bao-ve-moi-truong-la-rat-cap-bachd49164.html (In Vietnamese).

GreenInvest (2017). Green Foreign Direct Investment in Developing Countries. Geneva: UNEP Inquiry; Columbia Center on Sustaianbel Development; Greenlnvest.

Lalitha, S.F. (2002). Theoretical approach to decentralization: an introduction. Vidyodaya: Journal of Management Science, 1, vol. 1 and 2, pp. 117-141.

Mai, N.C., and S. Yu-Huay (2016). Fish death crisis prompts Vietnam waste water probe, Bloomberg, 4 May. Available at www.bloomberg.com/news/articles/2016-05-04/fish-death-crisis-promptsvietnam-to-probe-waste-water-pipes.

Mallampally, P., and K.P. Sauvant (1999). Foreign direct investment in developing countries. Finance and Development, vol. 36, pp. 34-37.

Minh Hong (2014). How big is the scale of Formosa Ha Tinh project?, 1 July. Available at https:// giaoduc.net.vn/Kinh-te/Quy-mo-du-an-Formosa-Ha-Tinh-Ion-den-dau-post146743.gd (In Vietnamese).

Nam Phuong (2016). Formosa incident, the main responsibility belongs to Ha Tinh province?, 18 November. Available at https://nongnghiep.vn/su-co-formosa-trach-nhiem-chinh-thuoc-vetinh-ha-tinh-post180677.html (In Vietnamese).

Nguyen, A.T., and L. Hens (2019). Human Ecology of Climate Change Hazards in Vietnam. Cham, Switzerland: Springer International Publishing.

Nhi, H. (2016). Formosa incident: expanding compensation for disadvantaged people, 11 February (In Vietnamese).

Organization for Economic Cooperation and Development (OECD) (2002). Foreign Direct Investment for Development - Maximizing Benefits, Minimizing Costs. Paris.

Pham, D.N., and M.N. Chau (2016). Vietnam's beaches littered with dead fish test country's new government. Chicago Tribune, 2 May. Available at www.chicagotribune.com/nation-world/ctvietnam-dead-fish-20160502-story.html.

Phuong Linh (2014). Formosa proposed to set up Vung Ang iron and steel special economic zone. Vnexpress, 25 June. Available at https://kinhdoanh.vnexpress.net/tin-tuc/doanh-nghiep/ formosa-de-xuat-lap-dac-khu-kinh-te-gang-thep-vung-ang-3009064.html (In Vietnamese). 
Thu Trang (2016). Clarify the responsibilities of the Ministry of Natural Resources and Environment in the Formosa incident. ThienNhien.Net, 17 November. Available at www.thiennhien.net/2016/ 11/17/lam-ro-trach-nhiem-cua-bo-tai-nguyen-va-moi-truong-trong-su-co-formosa/ (In Vietnamese).

United Nations Conference on Trade and Development (UNCTAD) (2018). World Investment Report. Sales No. E.18.II.D.4.

Vnexpress (2016). About Formosa project, 27 July. Available at http://tonghoixaydungvn.vn/tabid/169/ catid/472/item/7006/ve-du-an-formosa.aspx (In Vietnamese).

Vu, T.T.A., V.T. Le, and T.T. Vo. T.T. (2007). Provincial extralegal investment incentives in the context of decentralization in Vietnam: mutual beneficial or a race to the bottom? Research Working Paper under Project, No. 5088790-01. Ha Noi: UNDP.

Wit, L., and others (2012). Assessing decentralised policy implementation in Vietnam: the case of land recovery and resettlement in the Vung Ang Economic Zone. ISS Working Papers - General Series, 546. The Hague: Institute of Social Studies.

X.H. (2016). The big loophole in licensing investment for Formosa. Available at https://baomoi.com/lohong-lon-trong-cap-phep-dau-tu-cho-formosa/c/19952908.epi (In Vietnamese). 